\title{
O poprawianiu (ale też i o psuciu) systemu przeprowadzania awansów naukowych w Polsce w latach 1990-2017
}

\begin{abstract}
STRESZCZENIE. Artykuł przedstawia kluczowe problemy polskiego systemu awansów naukowych przeprowadzanych na uczelniach oraz w instytutach PAS i instytutach badawczych. Idzie o nadawanie - przez uprawnione jednostki naukowe - stopni naukowych: doktora i doktora habilitowanego. Autor, po krótkim przedstawieniu tej problematyki w czasach Polski Ludowej (lata 1945-1989) skupia się na ukazaniu ewolucji - i tej pozytywnej i tej złej, psującej ten system - systemu awansów naukowych. Artykuł odwołuje się (w warstwie „dowodowej”) do podstawowych aktów prawnych (ustaw i rozporządzeń) regulujących funkcjonowanie uczelni wyższych oraz - w szczególności - procedury nadawania stopni naukowych. Zdaniem autora w ostatnich kilkunastu latach zaczęły zachodzić w tym obszarze niepokojące zjawiska, które wymagają podjęcia (ale nie pozbawiających autonomii uczelni) działań usprawniających ten ważny system. Aby to uczynić, potrzebny jest konstruktywny dialog obu stron: państwa i uniwersytetu.
\end{abstract}

SŁOWA KLUCZOWE: uniwersytet, stopnie naukowe: doktor, doktor habilitowany, autonomia, Ministerstwo Nauki i Szkolnictwa Wyższego, akty prawne dotyczące szkolnictwa wyższego, sfery badań naukowych oraz awansów naukowych

\section{Wstęp}

Awanse naukowe ${ }^{1}$ są bardzo ważnym ogniwem w łańcuchu doskonalenia kadr zatrudnianych w uczelniach wyższych oraz w instytutach PAN i instytutach badaw-

${ }^{1} \mathrm{~W}$ tym artykule pod pojęciem „przeprowadzania awansów naukowych” będę rozumiał procedury nadawania stopni naukowych: doktora i doktora habilitowanego oraz procedurę opiniowania wniosków o nadanie przez Prezydenta RP tytułu naukowego profesora prowadzone przez rady wydziałów i rady instytutów uczelni wyższych oraz rady naukowe instytutów PAN i instytutów badawczych. Te procedury, rzecz jasna, są regulowane (a moim zdaniem przeregulowane) stosownymi 
czych. A w dłuższej perspektywie czasowej mają przemożny wpływ² na kondycję nauki uprawianej w Polsce czy nauki po prostu. Z jednej bowiem strony umożliwiają wymianę kadry naukowej z powodów naturalnego jej starzenia się. Osoby odchodzące w stan spoczynku zastępowane są przez osoby młode - z nadzieją, że sprostają wzrastającym wymaganiom, że wniosą swoistą „wartość dodaną”. Z drugiej zaś strony pozwalają najzdolniejszym na usamodzielnienie się i kierowanie własnymi zespołami badawczymi. Zaś osoby niespełniające coraz bardziej „wyśrubowanych” kryteriów też - niejako w sposób „naturalny” - przechodzą do pełnienia innych, co nie oznacza, że społecznie gorszych ról, np. nauczycielskich na uczelniach.

System awansów naukowych, aby był efektywny, musi być wsparty przemyślanym systemem ewaluacji: (1) nauczycieli akademickich i badaczy oraz (2) zatrudniających ich jednostek uczelnianych i instytutów badawczych - tzw. ocena parametryczna prowadzona przez KEJN. Zatem, aby można było mówić (i uzyskiwać w przyszłości, oby niezbyt odległej, założone, satysfakcjonujące wyniki) o dobrze funkcjonującym systemie awansów naukowych, muszą być ze sobą w wysokim stopniu sprzężone (por. Antonowicz i Brzeziński, 2013): (1) zasady oceny jednostek naukowych, które - jako spełniające w wysokim stopniu kryteria tych ocen - będą uprawnione do przeprowadzania przewodów awansowych oraz (2) zasady oceny pojedynczych badaczy podlegających tym ocenom. To, co teraz budzi uzasadniony niepokój osób zajmujących się tą problematyką i wywołuje dyskusje i protesty środowiska (zwłaszcza badaczy z kręgu nauk humanistycznych), to: przenoszenie zasad ocen jednostek naukowych (wydziałów i instytutów) na oceny pojedynczych osób oraz zastępowanie ewaluacji prowadzonej metodą peer review metodami „mechanicznymi”, merytorycznie niezinterpretowanymi, odwołującymi się do wskaźników bibliometrycznych: IF, SumIF, liczba cytowań według bazy Web of Science (WoS), h-Hirscha - bez wnikania w treść ocenianych dokonań: monografii, artykułów pomieszczonych w czasopismach (por. np. Brzeziński, 2015a, 2016; Towpik, 2015; Wróblewski, 2017; Zakrzewski, 2012; Żylicz, 2008, 2015).

$\mathrm{Na}$ te dyskusje prowadzone przez samych badaczy nakłada się bałagan legislacyjny oraz niezaspokojone apetyty ministerstwa, aby jak najwięcej regulować za pomocą rozporządzeń i instrukcji. Przykładem hiperregulacji, zresztą merytorycznie ułomnej (co dobitnie wykazał Zakrzewski, 2012), i - co gorsze (a może lepiej?) nie w pełni przestrzeganej - jest wydane jeszcze przez minister Barbarę Kudrycką rozporządzenie z dnia 1 września 2011 r. w sprawie kryteriów oceny osiągnięć osoby

przepisami prawnymi - ustawami i rozporządzeniami. I im poświęcę najwięcej uwagi. Analogiczne czynności awansowe prowadzone są także w dziedzinach sztuki, którymi w tym opracowaniu nie będę się zajmował.

${ }^{2}$ Oczywiście, że zdaję sobie sprawę z pierwszoplanowej roli czynnika ekonomicznego (\%PKB przeznaczony przez państwo na finansowanie szkolnictwa wyższego i badań naukowych), ale w niniejszej pracy będą od roli tego czynnika abstrahował. Nie sposób pisać o wszystkim. 
ubiegającej się o nadanie stopnia doktora habilitowanego o którym szczegółowo piszę w pkt E.

Do tego czynnika „prawno-organizacyjnego” włączyłbym jeszcze nacisk rozrośniętego, ponad racjonalną miarę, i w stopniu niespotykanym w Europie Zachodniej, sektora niepublicznego szkolnictwa wyższego ${ }^{3}$, który zabiega o przyznanie mu też uprawnień, które są - jak na razie - w większości przyznane uczelniom publicznym i takimż instytutom. Mam na myśli, przede wszystkim, uprawnienia do prowadzenia studiów magisterskich (jednolitych lub uzupełniających jako studia drugiego stopnia) oraz - $\mathrm{w}$ interesującym nas tu obszarze - do prowadzenia przewodów doktorskich. Wszystko to tworzy węzeł gordyjski. Spróbuję go jednak rozplątać. Chyba - i do tego rozwiązania bym się skłaniał - że skuteczniejszy może okazać się tu miecz Aleksandra Wielkiego.

\section{Trochę historii}

Przed odzyskaniem przez Polskę pełnej suwerenności procedury nadawania stopni naukowych oraz dwóch tytułów naukowych (profesora nadzwyczajnego i profesora zwyczajnego) podlegały silnej kontroli nie tylko ze strony ministerstwa, ale też odpowiednich komórek szczebla wojewódzkiego i centralnego PZPR. Wnioski awansowe były przez te komórki obligatoryjnie, nieformalnie, kontrolowane (i, wedle uznania, skutecznie blokowane, albo opóźniane). Ta praktyka postępowania decydentów szczebla politycznego nie była czymś odosobnionym. Była, co prawda, bardzo ważnym, ale tylko elementem składowym polityki o charakterze kontrolno-represyjnym prowadzonym przez aparat partyjny względem całego obszaru nauki, a szczególnie szkolnictwa wyższego.

Istotną rolę odgrywała - w pełni odgórnie powoływana - Centralna Komisja Kwalifikacyjna dla Pracowników Nauki CKK - utworzona w 1951 r. (ustawa z dnia 15 grudnia 1951 r. o szkolnictwie wyższym i o pracownikach nauki). Członków Centralnej Komisji Kwalifikacyjnej powoływał Prezes Rady Ministrów „spośród samo-

3 Ów rozrost szkolnictwa wyższego, a w nim swój istotny udział miał rozrost sektora niepublicznego szkolnictwa wyższego wprowadzil, przynajmniej nominalnie, do czołówki europejskiej jeśli chodzi o liczbę studiujących osób w Polsce. Wskaźnik scholaryzacji brutto (rok akademicki: 2015/2016) osiągnął wartość $48 \%$. To raczej powinno nas martwić, gdyż oznacza to, że aby utrzymać tak wysoką wartość wskaźnika scholaryzacji trzeba było systematycznie obniżać i kryteria rekrutacji na studia i ich poziom. Wszak i tu „działała” prawo rozkładu normalnego (krzywa Gaussa). Do tego dodajmy jeszcze ważny czynnik, który nazwać można „wolą przeżycia”. Idzie o to, że właściciele szkół niepublicznych, którzy zainwestowali w mury, aby uniknąć bankructwa zrobią wszystko, aby „przeżyć” - też obniżą poziom studiów (aby studenci wytrwali do końca studiów) i zgodzą się na przyjmowanie na studia każdego, który tylko uzna, że mógłby studiować. To pieniądz, zwłaszcza w czasach niżu demograficznego (czy, jak to nazwali Dominik Antonowicz i Bartłomiej Gorlewski, „demograficznego tsunami”, Antonowicz i Gorlewski, 2011) rządzi słabymi niby-uczelniami. 
dzielnych pracowników nauki” (art. 50 ust. 1 rzeczonej ustawy). Przewodniczącego powoływał Prezydent Rzeczypospolitej na wniosek Prezesa Rady Ministrów. Zaś zastępców i sekretarza powoływał Prezes Rady Ministrów. Komisję zlikwidowano w 1958 r. (por. ustawa z dnia 5 listopada 1958 r. o szkolnictwie wyższym). Ponownie powołano „odnowioną” Centralną Komisję Kwalifikacyjną do Spraw Kadr Naukowych (art. 19a ust. 2 ustawy z dnia 12 kwietnia 1973 r. o zmianie przepisów dotyczących stopni naukowych i tytułów naukowych oraz organizacji instytutów naukowo-badawczych) w 1973 r. W jej skład wchodzili „wybitni uczeni reprezentujący główne kierunki nauki jej przewodniczącego, zastępców, sekretarza oraz członków powoływał Prezes Rady Ministrów na wniosek Ministra Nauki, Szkolnictwa Wyższego i Techniki.

Ostatecznie CKK została zastąpiona na mocy ustawy z dnia 12 września 1990 r. o tytule naukowym i stopniach naukowych przez działającą do dnia dzisiejszego Centralną Komisję do spraw Tytułu Naukowego i Stopni Naukowych (aktualnie pod nazwą: Centralna Komisja do Spraw Stopni i Tytułów; por. strona internetowa: http://www.ck.gov.pl/articles/id/8.html). Także i ona podlegała, aż do maja 2017 r., ewolucji, ale o tym będzie mowa w pkt A.

Ten PRL-owski okres działalności wyższych uczelni i poddawania ich ideologicznej presji oraz funkcjonowania systemu awansów naukowych syntetycznie scharakteryzował Dominik Antonowicz (2015, pkt 4.1.2: „Szkolnictwo wyższe w okresie Polski Ludowej”, s. 153-181). Z kolei artykuły Krystyny Wojtczak (2016a, 2016b, 2017a, 2017b) dają bardzo wnikliwą analizę prawną, wspartą bogatym materiałem źródłowym, sytuacji awansów naukowych w okresie Polski Ludowej.

\section{Krytyczne punkty funkcjonowania systemu awansów naukowych}

Dokonującym się w Polsce po roku 1989 przemianom społeczno-politycznym i gospodarczym towarzyszyły doniosłe - wyznaczające (jak się okazuje) na wiele lat - zmiany o charakterze ustrojowym i organizacyjnym w sferze szkolnictwa wyższego i badań naukowych. Legislacyjny ton nadały tym przemianom dwie ustawy: (1) ustawa z dnia 12 września 1990 r. o szkolnictwie wyższym i (2) ustawa z dnia 12 września 1990 r. o tytule naukowym i stopniach naukowych. Obie ustawy zostały po 2000 r. zastąpione przez nowe, dostosowane do nowych warunków społeczno-politycznych (chociażby uchwalenie nowej Konstytucji RP). I tak, całym obszarem szkolnictwa wyższego i badań naukowych zawiadują dwie ustawy, pochodne względem tych wyżej wymienionych: (1) ustawa z dnia 27 lipca 2005 r. prawo o szkolnictwie wyższym (ostatnia zmiana wprowadzona do tekstu ustawy pochodzi z 2017 r.) oraz (2) ustawa z dnia 14 marca 2003 r. o stopniach naukowych i tytule naukowym oraz o stopniach i tytule w zakresie sztuki (ostatnia, i to znacząca, zmiana wprowa- 
dzona do tekstu ustawy pochodzi z 2017 r.). Tym ustawom towarzyszą - niestety często korygowane i uzupełniane - akty wykonawcze. Najważniejsze to - w ich wersjach aktualizowanych w roku 2016 - rozporządzenia: (1) rozporządzenie Ministra Nauki i Szkolnictwa Wyższego z dnia 26 września 2016 r. w sprawie warunków prowadzenia studiów oraz (2) rozporządzenie Ministra Nauki i Szkolnictwa Wyższego z dnia 30 września 2016 r. w sprawie szczegółowego trybu i warunków przeprowadzania czynności w przewodach doktorskich, w postępowaniu habilitacyjnym oraz w postępowaniu o nadanie tytułu profesora. Trzeba jeszcze wymienić trzecią ważną ustawę dla sfery szkolnictwa wyższego i badań naukowych: (3) ustawa z dnia 30 kwietnia 2010 r. o zasadach finansowania nauki (aktualizowana w 2016 r.). Stanowi ona prawną podstawę do przeprowadzanych okresowo przez KEJN tzw. ocen parametrycznych jednostek naukowych (w tym roku przeprowadzana jest kolejna ocena obejmująca dokonania jednostek w latach: 2013-2016). Tej ustawie towarzyszy akt wykonawczy: rozporządzenie Ministra Nauki i Szkolnictwa Wyższego z dnia 12 grudnia 2016 r. w sprawie przyznawania kategorii naukowej jednostkom naukowym i uczelniom, w których zgodnie z ich statutami nie wyodrębniono podstawowych jednostek organizacyjnych.

Chciałbym teraz skupić się na siedmiu sprawach ${ }^{4}$, które wymagają krytyczno-konstruktywnego naświetlenia i dokonania zmian w obowiązujących przepisach prawnych. Wymagają też - niekiedy przywrócenia poprzednich, proautonomicznych - regulacji prawnych. Będą to:

A. Zadania Centralnej Komisji - co należy zmienić (czy przywrócić);

B. Potrzeba sporządzenia nowej klasyfikacji dziedzin nauki i dyscyplin naukowych;

C. Potrzeba ustalenia nowych progów kadrowych dla jednostek ubiegających się o prawo nadania stopni naukowych i opiniowania wniosków o nadanie przez Prezydenta RP tytułu naukowego;

D. Skład komisji habilitacyjnych; miejsce przeprowadzania procedur awansowych;

E. Ministerialna instrukcja dla recenzentów powołanych w postępowaniu habilitacyjnym;

F. Art. 21a ustawy o stopniach naukowych i tytule naukowym...;

G. Nowy program ministra: „Doktorat wdrożeniowy”.

${ }^{4}$ Niektóre z prezentowanych tu propozycji były wcześniej przedstawione na dwóch konferencjach: J. Brzeziński, Co trzeba zmienić $w$ przepisach odnoszących się do awansów naukowych? Referat wygłoszony na konferencji zorganizowanej przez Konferencję Rektorów Uniwersytetów Polskich, Lublin 2014; J. Brzeziński, B. Marciniak, M. Pałys, Najważniejsze elementy zmian dla powstrzymania spadku poziomu awansów naukowych (habilitacje i doktoraty). Referat wygłoszony na konferencji zorganizowanej przez Prezydium Konferencji Rektorów Akademickich Szkół Polskich. Poznań 2015. 


\section{Ad. A. Zadania Centralnej Komisji - co należy zmienić (lub przywrócić)}

Centralna Komisja działająca przy Prezesie Rady Ministrów pełni funkcję centralnego organu administracji państwowej. Powoływana jest $\mathrm{w}$ drodze wyborów (tajnych) spośród osób posiadających tytuł naukowy profesora. Kandydatów na członków zgłaszają rady jednostek naukowych posiadających uprawnienia do nadawania stopnia doktora. Tak jest począwszy od $1991 \mathrm{r}$.

Dopiero ustawa z dnia 12 września 1990 r. o tytule naukowym i stopniach naukowych wprowadziła demokratyczne zasady wyboru członków Centralnej Komisji. Tym samym została zerwana zła „tradycja”, iż to Prezes Rady Ministrów - bez konsultacji ze środowiskiem naukowym i poza trybem wyborczym - powołuje nie tylko jej członków, ale przewodniczącego, zastępców i sekretarza. Po wprowadzeniu nowej ustawy z dnia 14 marca 2003 r. o stopniach naukowych i tytule naukowym oraz o stopniach i tytule w zakresie sztuki sprawy powołania członków oraz kierownictwa CK reguluje art. 33:

2. Centralna Komisja działa przy Prezesie Rady Ministrów i w zakresie wydawanych przez siebie decyzji pełni funkcje centralnego organu administracji rządowej.

3. Centralna Komisja opiniuje projekty aktów normatywnych dotyczących spraw związanych z nadawaniem stopni doktora i doktora habilitowanego oraz tytułu profesora, a także wyraża opinie w sprawie zatrudnienia w szkole wyższej na stanowisku profesora nadzwyczajnego osób nieposiadających stopnia doktora habilitowanego.

4. Przewodniczącego Centralnej Komisji powołuje Prezes Rady Ministrów spośród dwóch kandydatów przedstawionych przez Centralną Komisję z grona jej członków.

Pierwszym, powołanym w 1991 r. przez Prezesa Rady Ministrów - na podstawie wskazania (w głosowaniu tajnym) dwóch kandydatów, dokonanego na zebraniu wszystkich wybranych przez środowisko członków CK - przewodniczącym został prof. Jerzy Pelc († 2017). Ostatnim, powołanym w 2013 r. przez Prezesa Rady Ministrów, w tym samym trybie, spośród dwóch wskazanych przez zebranie wyborcze kandydatów, był prof. Antoni Tajduś.

W 2017 r. dokonano kolejnej zmiany rzeczonej ustawy za pomocą ustawy z dnia 21 kwietnia 2017 r. o zmianie ustawy o stopniach naukowych i tytule naukowym oraz o stopniach i tytule w zakresie sztuki oraz niektórych innych ustaw. Art. 33 ust. 3 zmienionej ustawy otrzymał nowe brzmienie: „3. Prezes Rady Ministrów powołuje przewodniczącego Centralnej Komisji z grona jej członków”. Wskazani (10 stycznia 2017 r.) - zgodnie z obowiązującym wówczas prawem - przez zebranie nowo wybranych członków CK dwaj kandydaci (prof. Antoni Tajduś i prof. Grzegorz Węgrzyn) nie byli przez Prezesa Rady Ministrów uwzględnieni - zgodnie z art. 5 ust. 1 rzeczonej ustawy:

1. Kandydatury na przewodniczącego Centralnej Komisji do Spraw Stopni i Tytułów przedstawione Prezesowi Rady Ministrów na podstawie art. 33 ust. 3 ustawy zmienianej w art. 1, w brzmieniu dotychczasowym, nie podlegają rozpatrzeniu. 
Prezes Rady Ministrów powołał w maju 2017 r. na przewodniczącego CK (na kadencję 2017-2020) prof. Kazimierza Furtaka. I tak zamknął się kolejny rozdział w historii Centralnej Komisji.

Tyle odniesień do historii Centralnej Komisji - i tej odległej i tej najnowszej rozpoczętej ustawą z 1990 r. Czy zasadne staje się, od czasu do czasu, pojawiające się w prasie czy na stronach portali internetowych pytanie: Czy dziś potrzebna jest taka, centralnie sterująca awansami naukowymi, a przez to mająca znaczący wpływ na rozwój (i poziom) badań naukowych w Polsce? W tym kontekście pojawia się też zarzut dotyczący jej komunistycznego rodowodu. Podobnie, od czasu do czasu, pojawia się też postulat likwidacji habilitacji (ta akurat ma dobre „urodzenie” - Humboldtowski uniwersytet!). Osobiście jestem zwolennikiem jej utrzymania (Brzeziński, 2015b) i usprawniania samej procedury, ale nie wszystkiego, co z nią zrobili twórcy ustawy z dnia 14 marca 2003 r. o stopniach naukowych i tytule naukowym oraz o stopniach i tytule w zakresie sztuki (tekst jedn. z 21 czerwca 2016 r.).

Do najważniejszych zadań CK zaliczyłbym:

Ogłaszanie i monitorowanie klasyfikacji dziedzin nauki i dyscyplin naukowych. Ważne jest, aby CK nie ulegała doraźnej presji instytucji państwa i czynników kościelnych, ale także prominentnych przedstawicieli dyscyplin naukowych, które zostały, ich zdaniem, „pominięte” w przedstawionej przez CK klasyfikacji (por. casus nowej dyscypliny naukowej: „nauki o rodzinie”; zob. pkt B). To zaś oznacza nie opiniowanie, a tworzenie klasyfikacji dziedzin nauki i dyscyplin naukowych, czyli powrót do poprzedniego zapisu ustawowego. Ministerstwo nie powinno obawiać się przyznania w tym zakresie autonomii Centralnej Komisji.

Przyznawanie uprawnień jednostkom naukowym do przeprowadzania przewodów doktorskich oraz postępowań habilitacyjnych. W związku z tym zadaniem, ważne jest też okresowe sprawdzanie poziomu prowadzonych spraw awansowych przez uprawnione jednostki naukowe. To wymaga także prowadzenia, w sposób ciągły aktualizowanej, bazy recenzentów, która powinna obejmować osoby o znaczących osiągnięciach naukowych i znane w środowisku z respektowania wysokich standardów badawczych i etycznych.

Jeżeli w mocy pozostanie art. 18a rzeczonej ustawy, to ważnym zadaniem w postępowaniach habilitacyjnych - nadal będzie kształtowanie komisji habilitacyjnych (także w części proponowanej przez rady jednostek). Także, zgodnie z obowiązującą dziś ustawą, CK ustala w postępowaniu o nadanie tytułu profesora skład pięciu recenzentów (art. 27 ust. 4 rzeczonej ustawy) oraz zatwierdza uchwałę jednostki naukowej w przedmiocie poparcia wniosku o nadanie tytułu profesora (art. 28 ust. 2 rzeczonej ustawy). I tu ważny jest dobór osób o wysokich kompetencjach naukowych i etycznych.

Opiniowanie wniosków o zatrudnienie na stanowiskach profesora nadzwyczajnego lub profesora wizytującego osób, które nie posiadają stopnia naukowego doktora habilitowanego, a jedynie stopień naukowy doktora. Zgodnie bowiem z art. 
115 ust. 1a ustawy z dnia 27 lipca 2005 r. prawo o szkolnictwie wyższym (tekst jedn. z 2016 r.) takie osoby mogą być zatrudnione jedynie wówczas, gdy Centralna Komisja wyda na ten temat pozytywną opinię.

Jeżeli utrzymany będzie (a nie powinien) art. 21a rzeczonej ustawy (por. pkt F), to Centralna Komisja powinna opracować, i konsekwentnie je respektować, zasady postępowania wobec decyzji rektorów i dyrektorów instytutów PAN i instytutów badawczych - nie wyrażając sprzeciwu i nie uchylając tej decyzji albo wyrażając sprzeciw i uchylając tę decyzję.

Oczywiście Centralna Komisja powinna mieć też zagwarantowaną możliwość wypowiadania się w kwestiach związanych z projektami aktów prawnych (ustawy i rozporządzenia) odnoszących się do problematyki nadawania stopni naukowych oraz opiniowania wniosków o nadanie tytułu naukowego, a także w kwestiach nowych regulacji dotyczących jej samej.

Jeśli zaś chodzi o tryb powoływania przewodniczącego Centralnej Komisji, to postuluję powrót do stanu prawnego sprzed ustawy z dnia 21 kwietnia $2017 \mathrm{r}$. o zmianie ustawy o stopniach naukowych i tytule naukowym oraz o stopniach i tytule w zakresie sztuki oraz niektórych innych ustaw.

\section{Ad. B. Potrzeba sporządzenia nowej klasyfikacji dziedzin nauki i dys- cyplin naukowych}

Podniesienie - opisanych w pkt A - progów ilościowych dla jednostek ubiegających się o pozyskanie uprawnień do nadawania stopni naukowych należy powiązać z klasyfikacją dziedzin nauki i dyscyplin naukowych. Ta, dziś obowiązująca, która została ogłoszona w rozporządzeniu Ministra Nauki i Szkolnictwa Wyższego z dnia 8 sierpnia $2011 \mathrm{r}$. w sprawie obszarów wiedzy, dziedzin nauki i sztuki oraz dyscyplin naukowych i artystycznych wymaga gruntownej zmiany - należy ją ograniczyć, uaktualnić, dostosować do, na przykład, rozwiązań europejskich OECD ${ }^{5}$.

W obowiązującej klasyfikacji mamy 13 dziedzin nauki (i 4 dziedziny sztuki). Niektóre są bardzo małe - „nauki prawne” (3 dyscypliny), „nauki matematyczne” (2 dyscypliny), „nauki leśne” (2 dyscypliny), „nauki teologiczne” (bez podziału na dyscypliny), „nauki weterynaryjne” (bez podziału na dyscypliny), „nauki farmaceutyczne” (bez podziału na dyscypliny), „nauki o zdrowiu” (bez podziału na dyscypliny), „nauki o kulturze fizycznej” (bez podziału na dyscypliny). Samodzielność niektórych dziedzin zaskakuje, np. dlaczego należy wyodrębniać „nauki o zdrowiu” z dziedziny „nauk medycznych”? Nie ma żadnego merytorycznego uzasadnienia dla tworzenia małych „imperiów dziedzinowych”. Także nie ma uzasadnienia dla rozdrobnienia dziedzin na bardzo wąskie czy podobne dyscypliny naukowe. Oto przy-

${ }^{5}$ Por. Wykaz dziedzin nauki i technik wedhug klasyfikacji OECD. http://www.ncbr.gov.pl/gfx/ ncbir/userfiles/_public/fundusze_europejskie/inteligentny_rozwoj/1_4_1_4_2015/2_wykaz_ dziedzin_nauki_i_technik_wedlug_klasyfikacji_oecd.pdf. 
kłady. Dziedzina „nauki leśne” została podzielona na dwie dyscypliny naukowe: „drzewnictwo” i „leśnictwo”. Dlaczego dyscyplina: „nauki o zarządzaniu” występuje w dwóch dziedzinach: „naukach humanistycznych” (poza dyscyplinami: „psychologią” i „socjologią”, które należą do dziedziny „nauk społecznych”!) i „naukach ekonomicznych”? Dlaczego w dziedzinie „nauk społecznych” wyodrębniono dwie podobne dyscypliny: „nauki o bezpieczeństwie” i „nauki o obronności”? Dlaczego w dziedzinie „nauk społecznych” wyodrębniono dwie podobne dyscypliny: „nauki o polityce” i „nauki o polityce publicznej”? Niektóre dyscypliny weszły do klasyfikacji na skutek zabiegania o to ze strony różnych, też bardzo wpływowych, środowisk. Podam jeden taki przykład. W dziedzinie „nauk humanistycznych” (a nie w dziedzinie „nauk społecznych”, obok dyscyplin naukowych: „pedagogiki”, „psychologii”, „socjologii”) znalazła się dyscyplina „nauki o rodzinie” (wbrew negatywnej opinii CK!). Projekt omawianego tu rozporządzenia był konsultowany, m.in. przez Konferencję Episkopatu Polski. W uzasadnieniu ${ }^{6}$ powołania nowej dyscypliny naukowej minister napisała:

[...] uwaga [Konferencji Episkopatu Polski - J.M.B.] dotycząca braku dyscypliny „nauki o rodzinie", której zamieszczenie w wykazie, z perspektywicznego punktu widzenia, jest uzasadnione. Uwaga ta została uwzględniona. Dyscyplina „nauki o rodzinie” została zamieszczona w dziedzinie nauk humanistycznych.

Pozostawiam to bez komentarza. Utworzenie niewielkiej liczby pojemnych i nierozdrobnionych na bardzo wąskie dyscypliny dziedzin nauki ułatwi, też, wprowadzenie w życie rozwiązań przedstawionych w pkt B. Zatem nie należy rozwijać listy dziedzin i dyscyplin nauki, ale próbować ją istotnie ograniczać. I nie ulegać presji różnych środowisk (to też element autonomii uniwersytetu). Takie „rozdrabnianie” nie jest dziś konstruktywnym rozwiązaniem.

\section{Ad. C. Potrzeba ustalenia nowych progów kadrowych dla jednostek ubiegających się o prawo nadania stopni naukowych i opiniowania wniosków o nadanie przez Prezydenta RP tytułu naukowego}

Zacznijmy od wycieczki w dość już odległą przeszłość - do ustawy z dnia 12 września 1990 r. o tytule naukowym i stopniach naukowych, a dokładniej do art. 3 ust. 1, 3, 5, który określał „minima kadrowe” dla jednostek naukowych (wydziałów i instytutów uczelni wyższych oraz instytutów PAN i instytutów badawczych, wówczas zwanych w skrócie JBR-ami).

Wymagania dla uzyskania uprawnień doktorskich wyglądały następująco: jednostka powinna zatrudniać w pełnym wymiarze czasu pracy nie mniej niż 8 osób z tytułem naukowym profesora lub stopniem naukowym doktora habilitowanego. Te osoby powinny reprezentować daną dziedzinę nauki, wyszczególnioną w aktual-

\footnotetext{
${ }^{6} \mathrm{http}: / /$ seminare.pl/pdf/rozporzadzenie-mnisw.pdf.
} 
nym wykazie dziedzin i dyscyplin naukowych, który ogłaszał przewodniczący Centralnej Komisji (dalej w skrócie: CK - o czym traktuje art. 5 ustawy). Pięciu z tych pracowników jednostki powinno reprezentować daną dyscyplinę nauki (wchodzącą do danej dziedziny nauki). Wszystkie osoby wchodzące do minimum kadrowego powinny być zatrudnione $\mathrm{w}$ jednostce $\mathrm{w}$ pełnym wymiarze czasu pracy.

Wymagania dla uprawnień habilitacyjnych: 12 osób z tytułem naukowym profesora lub stopniem naukowym doktora habilitowanego, reprezentujących daną dziedzinę nauki. $Z$ tego co najmniej 6 osób posiadających tytuł naukowy profesora. 5 osób powinno reprezentować daną dyscyplinę naukową wchodzącą do dyscypliny naukowej. Wszystkie osoby wchodzące do minimum kadrowego powinny być zatrudnione w jednostce w pełnym wymiarze czasu pracy.

W szczególnych sytuacjach CK mogła wyrazić zgodę, ale tylko każdorazowo dla danego przewodu - art. 8:

W razie braku w kraju jednostki organizacyjnej właściwej dla przeprowadzenia określonego przewodu doktorskiego lub habilitacyjnego, Centralna Komisja, działając na wniosek jednostki organizacyjnej lub z urzędu, może zarządzić uzupełnienie składu rady wskazanej przez siebie jednostki o osoby nie będące członkami tej rady. Osoby te mają uprawnienia członka danej rady w sprawach tego przewodu doktorskiego lub habilitacyjnego.

Słabością, później naprawioną, był wymóg zatrudnienia osób o których mówi art. 5 ustawy jedynie w pełnym wymiarze czasu pracy, ale bez dodatkowego zastrzeżenia, że dla tych osób powinno to być podstawowe miejsce zatrudnienia (a takie może być tylko jedno).

O ile wówczas nie były to łatwe, w sensie ilościowym, do spełnienia kryteria (zwłaszcza te odnoszące się do uprawnień habilitacyjnych!), to dziś, po ponad ćwierć wieku, są one już łatwiejsze do pokonania, jako że kadra samodzielnych pracowników uległa kilkakrotnemu zwiększeniu. Nastąpiła ich swoista inflacja. Jak by tego było mało, w ustawie z dnia 14 marca 2003 r. o stopniach naukowych i tytule naukowym oraz o stopniach i tytule w zakresie sztuki (z uwzględnieniem jej późniejszych nowelizacji ujętych w tekście jednolitym) dokonano jeszcze ich osłabienia:

dopuszczono, aby jednostka mogła uzupełnić brakujące do minimum kadrowego osoby o te, które „reprezentują pokrewne dziedziny nauki lub sztuki, w tym pokrewne dyscypliny naukowe i artystyczne" (art. 6 ust. 5) - dla wszystkich prowadzonych przewodów, a nie tylko każdorazowo dla poszczególnych wniosków;

- dopuszczono, aby w minimum kadrowym dla uprawnień habilitacyjnych zamiast - jeżeli nie podnieść wymagań, to przynajmniej utrzymać je na dotychczasowym poziomie - w miejsce 6 profesorów dopuszczono - tak, tak, to nie pomyłka - tylko 3 profesorów (art. 6 ust. 2);

- dopuszczono, aby do minimum kadrowego włączono także te osoby, które nabyły - w rozumieniu art. 21a - „uprawnienia równoważne z uprawnienia- 
mi doktora habilitowanego" (art. 6 ust. 1-3); o tym kuriozalnym rozwiązaniu więcej w pkt E.

Odnotować należy też dwie pozytywne zmiany:

- wymóg zatrudnienia w jednostce naukowej traktowanej jako podstawowa „w rozumieniu ustawy z dnia 27 lipca 2005 r. Prawo o szkolnictwie wyższym” (art. 6 ust. 1-2);

- wymóg zatrudnienia w jednostce nie krócej, niż jeden rok przed złożeniem wniosku (art. 5 ust. 4).

Naszym zdaniem jest kilka powodów, dla których jednostki zabiegają o uzyskanie uprawnień do nadawania stopni naukowych:

- prowadzenie awansów naukowych względem własnych pracowników. Awansowanie własnych pracowników na swoim „terytorium” sprzyja obniżaniu wymagań stawianych „swoim”. Jest to też - zwłaszcza gdy zniesiono zatwierdzanie przez CK uchwał rad jednostek w przedmiocie nadania stopnia doktora habilitowanego - latwy sposób pozyskiwania własnej kadry doktorów i doktorów habilitowanych do budowania minimów kadrowych dla prowadzenia studiów licencjackich i, zwłaszcza, magisterskich;

- posiadanie uprawnień jest premiowane przy ocenie parametrycznej jednostek naukowych. W aktualnie obowiązującej ustawie z dnia 30 kwietnia $2010 \mathrm{r}$. o zasadach finansowania nauki oraz rozporządzeniu Ministra Nauki i Szkolnictwa Wyższego z dnia 12 grudnia 2016 r. w sprawie przyznawania kategorii naukowej jednostkom naukowym i uczelniom, w których zgodnie z ich statutami nie wyodrębniono podstawowych jednostek organizacyjnych posiadanie uprawnień doktorskich jest oceniane na 30 pkt, a habilitacyjnych na 70 pkt i dodatkowo jednostka otrzymuje punkty za każdy nadany stopień naukowy i zaopiniowany (z sukcesem) wniosek profesorski;

- posiadanie jednego uprawnienia habilitacyjnego lub dwóch doktorskich umożliwia powołanie w jednostce studiów doktoranckich (art. 195 ust. 1 ustawy z dnia 27 lipca 2005 r. Prawo o szkolnictwie wyższym);

- posiadanie tylko jednego uprawnienia doktorskiego umożliwia przekształcenie szkoły wyższej w uczelnię akademicką, 2 uprawnień w akademię, 6 uprawnień w uniwersytet przymiotnikowy 7 , a 10 uprawnień w uniwersytet ${ }^{8}-$ art. $3^{3}$ rzeczonej ustawy;

7 Art. 3 ust. 3: „Wyraz »uniwersytet« uzupełniony innym przymiotnikiem lub przymiotnikami w celu określenia profilu uczelni może być używany w nazwie uczelni, której jednostki organizacyjne posiadają co najmniej sześć uprawnień do nadawania stopnia naukowego doktora, w tym co najmniej cztery w zakresie nauk objętych profilem uczelni”.

${ }^{8}$ Art. 3 ust. 1: „Wyraz »uniwersytet« może być używany w nazwie uczelni, której jednostki organizacyjne posiadają uprawnienia do nadawania stopnia naukowego doktora co najmniej w dziesięciu dyscyplinach, w tym co najmniej po dwa uprawnienia w każdej z następujących grup dziedzin nauki: 1) humanistycznych, prawnych, ekonomicznych lub teologicznych; 2) matematycznych, fizycznych, 
- posiadanie uprawnień ma też znaczenie prestiżowe (np. rankingi uczelni wyższych).

Co zatem należy zrobić, aby zatrzymać, i odwrócić, ten niebezpieczny dla jakości awansów naukowych proces?

Aby zablokować owo zjawisko inflacji kryterium ilościowego - liczba samodzielnych pracowników włączanych do minimum kadrowego - należy znacząco podnieść progi kadrowe. Przedstawiane już propozycje obejmują następujące wartości progowe:

- dla uprawnień doktorskich: 12 samodzielnych pracowników z danej dziedziny nauki, a w tym trzech profesorów z danej dziedziny nauki i ośmiu doktorów habilitowanych z danej dyscypliny nauki;

- dla uprawnień habilitacyjnych (i opiniowania wniosków o nadanie przez Prezydenta RP tytulu naukowego profesora): 18 samodzielnych pracowników $\mathrm{z}$ danej dziedziny nauki, a w tym dziewięciu profesorów z danej dziedziny nauki i ośmiu doktorów habilitowanych z danej dyscypliny nauki;

Dla wszystkich wyżej wymienionych osób dana jednostka powinna być podstawowym miejscem zatrudnienia. Te osoby powinny być zatrudnione w jednostce nie krócej niż rok przed złożeniem wniosku.

\section{Ad. D. Skład komisji habilitacyjnych; miejsce przeprowadzania pro- cedur awansowych}

Dotychczasowa praktyka awansowa w odniesieniu do nadawania stopni naukowych doktora habilitowanego wymaga nie tylko podwyższenia progów kadrowych dla jednostek ubiegających się o uzyskanie stosownych uprawnień, ani nie wystarczy przygotowanie nowej klasyfikacji dziedzin nauki i dyscyplin naukowych. Należy jeszcze - dla poprawy obiektywności i transparentności prowadzenia postępowań habilitacyjnych - wprowadzić korekty do samej procedury. I tak, po pierwsze, siedmioosobowe składy komisji habilitacyjnych o których mówi art. 18a ustawy z dnia 14 marca 2003 r. o stopniach naukowych i tytule naukowym oraz o stopniach i tytule w zakresie sztuki powinny być wyznaczane przez CK (rzecz jasna, trzeba by dopracować szczegóły techniczne tego rozwiązania, ale jak można było powierzyć wyznaczenie 4 osób z siedmioosobowego składu komisji: jej przewodniczącego, 2 recenzentów i 1 członka, tak też można powierzyć jej wyznaczenie jeszcze dwóch osób: 1 recenzenta i 1 członka; sekretarza komisji przedstawiałaby, jak dotychczas, jednostka naukowa wybrana przez kandydata do przeprowadzenia postępowania awansowego). Recenzentów powinno się wyznaczać z prowadzonej przez CK certyfikowanej listy pracowników samodzielnych. Taka lista powstawałaby w efekcie konsultacji z radami jednostek naukowych, które poosiadają uprawnienia habilita-

nauk o Ziemi lub technicznych; 3) biologicznych, medycznych, chemicznych, farmaceutycznych, rolniczych lub weterynaryjnych". 
cyjne (alternatywnie: z jednostkami kategorii A+ i A). Zauważmy, że taka praktyka: powoływania recenzentów spoza miejsca zatrudnienia kandydata i składu rady jednostki prowadzącej przewód awansowy obowiązuje już w przewodach doktorskich. I nie jest ona przez środowisko kontestowana. Taki sposób postępowania pozwoli zminimalizować (bo całkowicie tego problemu nie da się zlikwidować; mówienie, że tak jednak można zrobić, to idealizacja) wpływ na postępowanie awansowe czynników subiektywnych: znajomości (to samo, czasami przez wiele lat, miejsce pracy), współpracy na innych polach aniżeli naukowe i związane z pracą nauczycielską, nacisk przełożonych na bardziej pobłażliwe potraktowanie „naszego Jasia”, bo tyle już lat wiernie pracuje, bo będzie potrzebny do wypełnienia luki kadrowej po Kowalskim, który odchodzi na emeryturę, bo... Jeśli zaś chodzi o konflikt interesów, to (poza wskazanymi w ustawie ograniczeniami związanymi z miejscem zatrudnienia kandydata i receznetów nie ograniczałbym go, jak to czyni teraz CK, tylko do recenzentów, którzy: (a) nie powinni byli występować w przeszłości w roli promotora i recenzenta pracy doktorskiej, (b) nie powinni być recenzentami wydawniczymi monografii habilitacyjnej, (c) nie powinni mieć wspólnych z kandydatem publikacji, (d) nie powinni być w relacji przełożony - podwładny, (e) nie powinni być $\mathrm{w}$ relacjach rodzinnych z kandydatem, (f) nie powinni być w konflikcie osobistym z kandydatem. Obowiązek wskazania konfliktu interesów powinien spoczywać na członku komisji habilitacyjnej. Rozszerzyłbym go na pozostałych członków komisji. Etyczne znaczenie unikania konfliktu interesu w procedurach recenzenckich jest mocno zaakcentowane w kodeksach etycznych (por. Brzeziński i Doliński, 2014): Kodeks etyki pracownika naukowego (KSEN, 2016) czy Dobre praktyki w procedurach recenzenckich $w$ nauce (ZEN, 2011).

Niezmiernie ważne, lamiące dotychczasową praktykę awansową, jest przeprowadzanie postępowania habilitacyjnego poza jednostką zatrudniającą kandydata. To także ma wpływ i na transparentność postepowania, i na jego obiektywizm. Rada przeprowadzająca postępowanie habilitacyjne byłaby wskazywana przez CK - bez możliwości (poza potencjalnym, wyraźnie określonym, konfliktem interesów) odmowy poprowadzenia tego postępowania. Teraz jednostki, bez obowiązku wytłumaczenia się, odmawiają kandydatom (zwłaszcza tzw. trudnym) przyjęcia ich wniosków. W takiej sytuacji CK korzysta z przysługującego jej uprawnienia i sama wyznacza radę do przeprowadzenia postepowania awansowego, a ta już nie może odmówić poprowadzenia postępowania (art. 18a ust. 3 ustawy o stopniach naukowych i tytule...).

Niestety, mimo powtarzanych apelów o przeprowadzanie postępowań habilitacyjnych oraz opiniowanie wniosków profesorskich poza macierzystą jednostką kandydata, propozycja ta nie spotkała się z zainteresowaniem decydentów. A i środowisko, poza tym, że publicznie wykazuje „zrozumienie” dla tej zmiany, nie robi nic, aby ją urzeczywistnić. 
I jeszcze jedna sprawa. $\mathrm{W}$ tzw. nowej procedurze przeprowadzania postępowania habilitacyjnego zostało ono całkowicie odpersonalizowane. Ewentualny kontakt z kandydatem (zaproszenie go na posiedzenie komisji) może mieć miejsc tylko wówczas, gdy występują jakieś, wymagające wyjaśnienia ze strony habilitanta, nieprawidłowości (art. 18a ust. 10 ustawy z dnia 14 marca 2003 r. o stopniach naukowych i tytule...). W podobnej sytuacji znajduje się też rada jednostki naukowej, która - odnosząc się do tekstu opinii (na ogół zreferowanej przez sekretarza komisji) - musi podjąć ważną decyzję: przychylić się do opinii komisji i (zgodnie z art. 18a ust. 8 rzeczonej ustawy) podjąc uchwałę w przedmiocie: „nadania lub odmowy nadania stopnia doktora habilitowanego", albo nie przychylić się do tej opinii i wówczas głosować własny kontrwniosek (jakie to czyni problemy - i jak je rozwiązać - wskazali Brzeziński i Izdebski, 2016). Jestem zdania, że przed podjęciem uchwały o nadaniu stopnia doktora habilitowanego rada jednostki, bez konieczności uzasadniania, powinna mieć możliwość zapoznania się z kandydatem. Najlepiej jakby wygłosił wykład na temat przez siebie wybrany. Nie postuluję powrotu do klasycznego kolokwium habilitacyjnego, ale wygłoszenie wykładu, to minimum kontaktu rady jednostki z habilitantem.

Według art. 18a ust. 8 członkowie komisji habilitacyjnej zobowiązani są do przyjęcia opinii o nadaniu lub odmowie nadania stopnia doktora habilitowanego. Głosowanie w tej sprawie ma charakter jawny. To jest jedyne takie rozwiązanie zapisane w ustawie o stopniach naukowych i tytule... Wszystkie głosowania w sprawach osobowych mają (i powinny mieć) charakter głosowań tajnych. Dlaczego w tym jednym przypadku ma być inaczej? Tym bardziej, że rada jednostki jest ustawowo zobowiązana do podejmowania uchwały o nadaniu lub odmowie nadania stopnia w głosowaniu tajnym (art. 20 ust. 1 ustawy). Oczywiście, kandydat może zażądać głosowania tajnego w komisji, ale chyba nie było dotychczas ani jednego takiego przypadku. Zapewne jest to związane z tym, że komisja może odbywać swoje posiedzenie $\mathrm{w}$ formie telekonferencji (co już bywa nadinterpretowane jako dopuszczalność kontaktowania się niektórych członków komisji z tymi zgromadzonymi w siedzibie jednostki za pomocą skype’a). Obawiam się, że wygodnictwo członków komisji doprowadzi, z czasem, do tego, że będziemy zachowywali się jak w $M a-$ triksie.

\section{Ad. E. Ministerialna instrukcja dla recenzentów powołanych w po- stępowaniu habilitacyjnym}

Rozporządzenie Ministra Nauki i Szkolnictwa Wyższego z dnia 1 września $2011 \mathrm{r}$. w sprawie kryteriów oceny osiągnięć osoby ubiegającej się o nadanie stopnia doktora habilitowanego stanowi przykład nadmiernej ingerencji państwa w czynności rad jednostek naukowych i wyznaczanych przez nie recenzentów, opiniujących rozprawę habilitacyjną oraz towarzyszący jej pozostały dorobek (naukowy, organizacyjny, dydaktyczny, popularyzatorski, w zakresie współpracy międzynaro- 
dowej). W tym rozporządzeniu określono, co powinno składać się na dorobek naukowy osoby ze stopniem naukowym doktora przystępującej do habilitacji. Można je odebrać jako wyraz braku zaufania do kompetencji rad wydziałów i instytutów, iż mogłyby one, nie pomijając istotnych elementów, trafnie i rzetelnie ocenić poziom naukowy dorobku habilitanta. Jeżeli potraktować poważnie ową swoistą ,instrukcję obsługi" habilitanta, to nasuwa się pytanie: jak to się stało, że przez dziesiątki lat wykształciliśmy, nie tak mało przecież, dobrych fachowców (w tym i ministrów)?

Rozporządzenie wymienia dokonania naukowe w obszarach: (a) nauk humanistycznych, (b) nauk społecznych, (c) nauk ścisłych, (d) nauk technicznych nauk przyrodniczych, nauk rolniczych, leśnych i weterynaryjnych oraz nauk medycznych, nauk o zdrowiu oraz nauk o kulturze fizycznej, (e) sztuki.

Pomijając, może mniej ważne, szczegóły skupię się wyłącznie na tych najistotniejszych, które świadczą o jego nikłej - zwłaszcza od kilku lat - przydatności (przy założeniu, że taki dokument jest potrzebny).

1. Wybór baz obejmujących czasopisma naukowe. Rozporządzenie wymienia bazy: Web of Science WoS, Journal Citation Reports JCR, ERIH.

A. Web of Science WoS (aktualnie: Web of Science Core Collection). Jest to narzucona przez środowisko nauk ścisłych, przyrodniczych, medycznych i technicznych międzynarodowa baza czasopism naukowych. Znacznie lepszym rozwiązaniem byłoby rozbicie monopolu tej jednej bazy i uzupełnienie jej o bazę SCOPUS (o czym niżej). Zawsze to lepiej, gdy będziemy honorować więcej, aniżeli tylko jedną (i to wcale niereprezentatywną dla całego obszaru nauk) baz. Zgadzam się z opinią fizyka, Jakuba Zakrzewskiego (Zakrzewski, 2012, s. 3):

Jest to jedna z najlepszych baz, obejmująca różne dziedziny nauki, ale jako taka nie jest optymalna w poszczególnych dziedzinach. Nie ma merytorycznego powodu, by stosować dla wszystkich jedną bazę, przecież i tak - mam nadzieję - nikt nie ma zamiaru porównywać medyków czy biologów z matematykami czy geografami, bo nie można, ze względu na inne tradycje i zwyczaje naukowe.

Można, niejako wstępnie, zobaczyć w jakich czasopismach publikuje habilitant, ale to nie powinno oznaczać, że te dobre czy najlepsze znajdują się wyłącznie w WoS. Przecież nie tylko specyfika nauk humanistycznych sprawia, że baza WoS jest mało przydatna, ale też w naukach ścisłych nie ma zgody specjalistów co do tego, że można tylko jedną bazę wyodrębnić i jej pozostać wiernym. Cytowany tu J. Zakrzewski pisze, że dla matematyków wartościową bazą jest baza MathSciNet Amerykańskiego Towarzystwa Matematycznego. Zatem, ale tylko pomocniczo, kilka baz ogólnych: WoS, SCOPUS, Google Scholar oraz, jak sądzę, kilka specjalistycznych, poważanych w danym środowisku, jak przywołana wyżej baza MathSciNet.

B. ERIH (European References Index for the Humanities). Baza zamknięta w 2014 r. Aktualnie, od lipca 2014 r., budowana jest nowa, rozszerzona (o nauki społeczne) jej wersja pod nazwą: ERIH PLUS (European References Index for the 
Humanities and Social Sciences) prowadzona przez Norwegian Social Science Data Services. Jak jednak pisał 7 lipca 2014 r. na swoim popularnym w środowisku badaczy blogu: Warsztat badacza, Emanuel Kulczycki9:

Twórcy podkreślają, że ERIH Plus jest listą referencyjną czasopism publikowanych we wszystkich europejskich językach. Oznacza to, że ERIH Plus nie zamienia się w żadną bazę indeksującą czy ewaluacyjną. [...] Czasopisma mogą być zgłaszane w sposób ciągły i - co bardzo ważne - wszyscy mają prawo zgłosić czasopismo (redaktorzy, wydawcy, autorzy, bibliotekarze itd.). [...] Zgłoszenie musi zawierać: 1.ISSN, 2. Tytuł czasopisma, 3. Język. 4. Sugerowaną dyscyplinę (lub dyscypliny). [...] Oczywiście kwestią otwartą pozostanie, jak w tej sprawie zachowają się odpowiednie gremia: czy uznają ERIH-a Plus za kontynuację ERIH-a (co wcale nie jest takie oczywiste) i czy będą honorowały „bycie na ERIH-u Plus” jako „bycie na ERIH-u”. [...] Może pojawić się jednak problem dewaluacji tej listy. Jeśli na ERIH-u Plus 1/3 czasopism to będą czasopisma polskie (a w sumie o to chodzi w listach referencyjnych), to pojawi się pytanie o to, jak traktować takie „indeksowanie na ERIH-u Plus”.

Dziś (lipiec 2017 r.) wiemy, że ERIH PLUS nie wyparł ERIH-a, który (paradoks - respektowana jest nieaktualna od trzech lat baza, a nowej ministerstwo nie zauważyło!). ERIH PLUS jest bazą typu „koncert życzeń” - każdy się może na nią wpisać. Najlepsze rozwiązanie w tej sytuacji, to wycofanie z oficjalnych aktów prawnych bazy ERIH i niewprowadzanie ERIH PLUS.

Najlepszym (zwłaszcza dla nauk humanistycznych i społecznych) rozwiązaniem, jeśli chodzi o bazy o zasięgu międzynarodowym, jest oficjalne uznanie bazy SCOPUS i powiązanej z nią SCImago Journal Rank (SJR indicator). Trzeba zauważyć, że SJR indicator jest „konkurencyjną” względem wskaźnika IF (wyliczanego dla czasopism ujętych w bazie Journal Citation Reports) miarą rangi czasopisma.

2. Ślepe przywiązanie do wskaźników bibliometrycznych. Rozporządzenie zaleca, aby przy ocenie dorobku naukowego habilitanta odwoływać się do kilku wskaźników bibliometrycznych: IF, SumIF , h-Hirscha, liczba cytowań. Biorąc pod uwagę liczne zaostrzenia co do wartości wskaźnika Impact Factor (IF) budowanego według bazy WoS (por. DORA, 2012; EASE, 2012; Brzeziński, 2015a; Towpik, 2015; Wróblewski, 2017) należałoby, z bardzo dużą dozą ostrożności, podchodzić do korzystania z tego wskaźnika (przecież pierwotnie pomyślnego jako o wskaźnika służącego do oceny czasopisma, a nie zamieszczonego w nim artykułu). Absolutnie nie powinno się korzystać z takiego kuriozalnego wskaźnika, jakim jest „sumaryczny impact factor publikacji naukowych według listy Journal Citation Reports (JCR), zgodnie z rokiem opublikowania” (§ 4.1 rzeczonego rozporządzenia). I tak, że ograniczę się do przedstawienia opinii tylko dwóch znaczących międzynarodowych organizacji: według EASE (2012, s. 139):

9 http://ekulczycki.pl/warsztat_badacza/erih-plus-zostal-uruchomiony/. 
European Association of Science Editors zaleca, aby kryterium wskaźnika oddziaływania czasopisma posługiwać się wyłącznie - i to z wielką ostrożnością - do oceny i porównywania jedynie wpływu czasopism jako takich, a nie do oceny poszczególnych prac. Z pewnością zaś nie należy go wykorzystywać do oceniania badaczy lub programów badawczych, tak bezpośrednio (directly), jak i zastępczo (as a surrogate).

według DORA (2012, s. 504):

1. Nie należy stosować danych bibliometrycznych czasopism (journal-based metrics), takich jak Journal Impact Factors, jako zastępczej miary jakości poszczególnych artykułów naukowych, do oceniania wkładu konkretnych badaczy czy podejmowania decyzji o ich zatrudnieniu, promowaniu lub finansowaniu. [...]

18. Należy kwestionować praktykę niewłaściwego wykorzystywania Journal Impact Factors do oceny badań naukowych, a wspierać i rozpowszechniać sposoby opierające się na wartości i oddziaływaniu konkretnych wyników badań.

I jeszcze jedna uwaga. Dlaczego wartość wskaźnika h-Hirscha i liczba cytowań artykułów miałyby być obliczane tylko według bazy WoS? Dlaczego nie dopuszcza się możliwości obliczania wartości obu wskaźników według bazy Google Scholar (uwzględniającej prace publikowane w języku polskim - książki, artykuły i rozdziały w pracach zbiorowych)? Ta baza jest „przyjazna” szczególnie dla badaczy z obszaru humanistyki (język polski!).

Konkluzja. Moim zdaniem, najprościej byłoby odstąpić od tego rozporządzenia. Jest ono, tak po prostu, niedobre.

\section{Ad. F. Art. 21a ustawy o stopniach naukowych i tytule naukowym...}

Chciałbym teraz skupić uwagę Czytelnika na pewnej osobliwości obowiązującej ustawy o stopniach i tytule..., a mianowicie na jej art. 21a. Brzmi on następująco:

1. Osoba, która uzyskała stopień doktora w Rzeczypospolitej Polskiej lub za granicą i podczas pracy w innym państwie przez co najmniej pięć lat kierowała samodzielnie zespołami badawczymi oraz posiada znaczący dorobek i osiągnięcia naukowe, zatrudniona na stanowisku profesora nadzwyczajnego lub profesora wizytującego, nabywa uprawnienia równoważne uprawnieniom wynikającym z posiadania stopnia doktora habilitowanego na podstawie decyzji:

1) rektora - jeżeli jest zatrudniona w szkole wyższej;

2) dyrektora instytutu naukowego Polskiej Akademii Nauk - jeżeli jest zatrudniona w instytucie Polskiej Akademii Nauk;

3) dyrektora instytutu badawczego - jeżeli jest zatrudniona w instytucie badawczym.

2. Podmioty wskazane w ust. 1 pkt 1-3 przekazują Centralnej Komisji decyzję, o której mowa w ust. 1, wraz z opisem kariery zawodowej i wykazem publikacji osoby, o której mowa w ust. 1.

3. Decyzja, o której mowa w ust. 1, wchodzi w życie po upływie czterech miesięcy od dnia jej otrzymania przez Centralną Komisję, jeżeli w tym okresie Centralna Komisja, w drodze decyzji administracyjnej, nie wyraziła sprzeciwu i nie uchyliła tej decyzji. 
4. Na decyzję Centralnej Komisji podmiotom, o których mowa w ust. 1 pkt 1-3, przysługuje, w terminie 30 dni od dnia jej otrzymania, skarga do właściwego sądu administracyjnego (podkreśl. - J.M.B.).

To, co szczególnie niepokoi w tej nowej, ale nie w pełni oryginalnej (o czym niżej) koncepcji powiększenia, za cenę jakości i odejścia od tradycji akademickiej, liczby kadry samodzielnych pracowników nauki to:

- możliwość włączenia tak awansowanej osoby do minimum kadrowego jednostki ubiegającej się o uzyskanie (nieutracenie) uprawnień do nadawania stopni naukowych. I tu ujawnia się pewien paradoks: osoba, która nie poddała się standardowej procedurze habilitacyjnej, która weszła do grona samodzielnych pracowników nauki niejako „kuchennymi schodami”, na mocy jednoosobowo podjętej decyzji swojego przełożonego (rektora, dyrektora instytutu) będzie decydowała o losach wniosków awansowych poprowadzonych w standardowy sposób;

- możliwość - oprócz prowadzenia prac doktorskich i ich recenzowania - opiniowania wniosków habilitacyjnych;

- możliwość występowania o uzyskanie tytułu naukowego profesora z wszystkimi przypisanymi temu tytułowi przywilejami.

Jest to powrót do idei nadawania doktorom uprawnień promotorskich, która była bardzo bliska resortowi wówczas, gdy chciał likwidacji habilitacji. Potem, pod naporem opinii środowiska akademickiego (też list 44), resort wycofał się z tego pomysłu, ale - jak się okazuje - tylko na krótko. Czy nie przypomina to regulacji $\mathrm{z}$ lat 6o. ubiegłego wieku? To według tekstu jednolitego ustawy z dnia 5 listopada 1958 r. o szkolnictwie wyższym (ogłoszonego obwieszczeniem Ministra Oświaty i Szkolnictwa Wyższego z dnia 17 stycznia 1969 r.) postanowiono, iż stanowisko docenta może zajmować też osoba (taka, która nie ma stopnia doktora habilitowanego), która (art. 78, ust. 2):

[...] posiada co najmniej stopień doktora w zakresie danej lub pokrewnej dziedziny nauki oraz odpowiedni dorobek naukowy lub zawodowy, osiągnięty po uzyskaniu tego stopnia, i która wykazała się przygotowaniem do prowadzenia samodzielnej pracy naukowej, dydaktycznej i wychowawczej.

Mało tego (art. 78 ust. 3):

W wyjątkowych przypadkach uzasadnionych potrzebami szkoły można na stanowisko docenta powołać osobę, która, nie mając stopnia naukowego określonego w ust. 1 [doktora - J.M.B.] i stażu pracy na stanowisku pracownika naukowo-dydaktycznego lub naukowo-badawczego, posiada jednak osiągnięcia w pracy naukowej [podkreśl. - J.M.B.] lub w twórczej pracy zawodowej niezbędne do pełnienia funkcji docenta. 
Ta regulacja została powtórzona w ustawie z dnia 12 kwietnia 1973 r. o zmianie przepisów dotyczących stopni naukowych i tytułów naukowych oraz organizacji instytutów naukowo-badawczych (art. 38 ust. 2).

Ale nawet $\mathrm{w}$ tamtych czasach, docent bez habilitacji nie mógł pełnić funkcji recenzenta $\mathrm{w}$ przewodach habilitacyjnych (art. 19 ust. 3 ustawy z dnia 31 marca 1965 r. o stopniach naukowych i tytułach naukowych - tekst jedn. z 11 września 1985 r.). Mógł natomiast pełnić funkcje promotora i recenzenta w przewodach doktorskich.

Trzeba też zwrócić uwagę na ust. 3 art. 21a. CK ma 4 miesiące czasu na wyrażenie sprzeciwu i, „w drodze administracyjnej”, uchylenie decyzji rektora/dyrektora. Po tym czasie staje się ona prawomocna.

Tę regulację postrzegam jako ułatwienie dostępu słabym uczelniom (przede wszystkim niepublicznym, bo to one borykają się z problemem zatrudnienia kadry samodzielnych pracowników naukowo-dydaktycznych) w celu poprowadzenia nowych kierunków studiów. Uważam, że zmiany powinny raczej wymuszać podnoszenie wymagań, a nie je obniżać; nie idzie wszak o to, aby jeszcze zwiększyć liczbę byle jak wykształconej młodzieży, ale aby kształcić na przyzwoitym poziomie. Moim zdaniem - jeżeli w ogóle (?) - art. 21a powinien dawać tylko uprawnienia do wchodzenia do minimów kadrowych studiów pierwszego stopnia o profilu praktycznym o których mówi rozporządzenie Ministra Nauki i Szkolnictwa Wyższego z dnia 26 września 2016 r. w sprawie warunków prowadzenia studiów. Ale najlepiej byłoby pozbyć się tego wstydliwego i budzącego skojarzenia z praktykami z niechlubnego okresu w najnowszej historii Polski. Nie sądzę, aby to była właściwa droga wzmacniania szkolnictwa wyższego, a zwłaszcza jego sektora niepublicznego (wszak gros decyzji właśnie z niego wychodzi).

\section{Ad. G. Nowy program ministra: „Doktorat wdrożeniowy”}

Najnowszy pomysł ministerstwa odnosi się do zacieśnienia związków nauki ze sferą gospodarki. Owym zwornikiem ma być otwarcie nowej ścieżki awansu naukowego na poziomie doktorskim osób pracujących, też twórczo, w sferze szeroko pojętej gospodarki. W najnowszej nowelizacji ustawy z 14 marca 2003 r. o stopniach naukowych i tytule... - ustawa z dnia 21 kwietnia 2017 r. o zmianie ustawy o stopniach naukowych i tytule naukowym oraz o stopniach i tytule w zakresie sztuki oraz niektórych innych ustaw wprowadzono nową konstrukcję: „doktor wdrożeniowy”. Kandydaci zainteresowani tak przedsiębiorczo nachylonym doktoratem zdobywaliby go w jednostce naukowej prowadzącej studia doktoranckie i współpracującej w tym zakresie z przedsiębiorcami zatrudniającymi uczestników studiów doktoranckich. Ta jednostka wchodziłaby do programu: „Doktorat wdrożeniowy” uruchomionego przez ministra. O finasowanie studiów doktoranckich w ramach tego programu mogłyby się ubiegać te jednostki naukowe, które prowadzą studia dokto- 
ranckie i posiadają przyznaną w ocenie parametrycznej kategorię A+ albo A. Środki byłyby przyznawane w drodze corocznego konkursu.

Ustawa przewiduje też, iż zatrudniający kandydata przedsiębiorca powoła spośród swoich pracowników „opiekuna pomocniczego” (co najmniej ze stopniem naukowym doktora, pięcioletnim doświadczeniem uczestniczenia $\mathrm{w}$ „pracach badawczo-rozwojowych" i posiadającego znaczące „osiągnięcia w zakresie opracowania i wdrożenia w sferze gospodarczej lub społecznej oryginalnego rozwiązania projektowego, konstrukcyjnego, technologicznego lub artystycznego, o ponadlokalnym zakresie oraz trwałym i uniwersalnym charakterze").

Ustawa, w związku z programem „Doktorat wdrożeniowy”, rozszerzyła (nowe brzmienie ust. 1 i 3 art. 13) definicję doktoratu o aspekty wdrożeniowe (tekst wyróżniony):

Art. 13.1. Rozprawa doktorska, przygotowywana pod opieką promotora albo pod opieką promotora i promotora pomocniczego, powinna stanowić oryginalne rozwiązanie problemu naukowego lub oryginalne rozwiązanie problemu w oparciu o opracowanie projektowe, konstrukcyjne, technologiczne, lub oryginalne dokonanie artystyczne, oraz wykazywać ogólną wiedzę teoretyczną kandydata w danej dyscyplinie naukowej lub artystycznej oraz umiejętność samodzielnego prowadzenia pracy naukowej lub artystycznej. [...]

3. Rozprawę doktorską może stanowić praca projektowa, konstrukcyjna, technologiczna, wdrożeniowa lub artystyczna, jeżeli odpowiada warunkom określonym w ust. 1. [podkreśl. - J.M.B.].

Nie wydaje mi się, aby - realizując wizję zacieśnienia więzi nauki z otoczeniem „społeczno-gospodarczym” - akurat potrzebne było poszerzenie ram pracy doktorskiej (może być ona teraz także „wdrożeniowa”) oraz narzucenie współpracy promotora (wyznaczanego przez radę jednostki) z „opiekunem pomocniczym” (wyznaczanym, spośród pracowników przedsiębiorstwa, przez przedsiębiorcę zatrudniającego doktoranta). Czy obligatoryjne wyznaczanie przez przedsiębiorcę opiekuna pomocniczego należy odczytywać jako wyraz troski o to, aby praca doktorska miała de facto charakter wdrożeniowy? Zauważmy jeszcze, że rada jednostki może także powołać promotora pomocniczego. Jeżeli tak się stanie, to w jakiej względem siebie relacji będą pozostawały te dwie osoby pełniące role pomocnicze?

Programem może być objętych 500 osób rocznie. I nie jest to tani program. Ze środków „budżetu państwa” (art. 7 ust. 1), w 2017 r. planuje się wydanie: 5170 tys. zł., ale od 2018 r. koszty znacząco rosną: 2018 r. -26350 tys. zł, 2019 r. -47530 tys. zł, 2020 r. -68720 tys. zl, a w latach 2021-2026 - po 84750 tys. zł rocznie. Pytanie: a co z finansowym udziałem w programie przedsiębiorców? Wszak to dla nich będą kształceni doktoranci.

Doktorat, jako stopień naukowy, będzie nadawała rada danej jednostki uczelni albo instytutu badawczego czy instytutu PAN. Dana osoba będzie się legitymowała 
stopniem doktora sensu proprio określonej dziedziny nauki i dyscypliny naukowej, a nie stopniem doktora wdrożeniowego. Dodajmy jeszcze, że takie doktoraty będą mogły być prowadzone - w ramach programu „Doktorat wdrożeniowy” tylko w jednostkach kategorii A+ i A, a więc przez elitę jednostek naukowych. Ta zaś raczej prostą „wdrożeniówką” się nie zajmuje. Być może niektóre wątpliwości rozstrzygnie zapowiadane rozporządzenie ministra. Troszcząc się o wysoki poziom naukowy stopni naukowych, nie rozmywajmy jednocześnie ich formuły.

\section{Wnioski}

1. System awansów naukowych w powojennej Polsce przeszedł długą i krętą z powodów politycznych - drogę:

- pierwsza połowa lat 50. - do przełomu październikowego: pełna kontrola polityczna,

- lata 60.: m.in. docenci „marcowi”,

- lata 80.: pozorna „odwilż” (pod presją masowego ruchu Solidarności) na ich początku: wybory rektorów, dziekanów; też dopuszczono możliwość wyboru dyrektorów instytutów;

- „przykręcenie śruby” przez ministra Benona Miśkiewicza w nowelizacji ustawy o szkolnictwie wyższym z 4 maja 1982 r., przeprowadzonej w 1985 r.: m.in. art. 6 ust. 2 obwieszczenia Ministra Nauki i Szkolnictwa Wyższego z 11 września 1985 r. w sprawie ogłoszenia jednolitego tekstu ustawy z dnia 4 maja 1982 r. o szkolnictwie wyższym:

Właściwy minister lub rektor może, do dnia 30 listopada 1985 r., oświadczyć w formie pisemnej, że nie potwierdza pełnienia funkcji przez osobę spośród wymienionych w ust. 1 [organy jednoosobowe szkoły oraz kierownicy i ich zastępcy jednostek organizacyjnych szkoły - J.M.B.]; w takim wypadku osoba ta sprawuje swoją funkcję do dnia 30 listopada 1985 r., a na pozostałą część kadencji rektora powołuje właściwy minister, prorektora właściwy minister na wniosek rektora, a do pełnienia pozostałych funkcji - rektor za zgodą właściwego ministra [podkreśl. - J.M.B.].

Trzeba zauważyć swoistą grę słów. Otóż minister nie odwoływał, a tylko nie potwierdzał pełnienia funkcji. Poza tym wszystkie stanowiska kierownicze były obsadzane za jego zgodą. Pełna kontrola polityczna. Wszystkie stanowiska kierownicze wymagały akceptacji ministra; nawet kandydatów na stanowiska rektora, prorektorów, dziekana i prodziekanów ostatecznie zatwierdzał minister.

Taki brutalny nacisk polityczny na środowisko naukowe wywarl, rzecz jasna, wpływ na mechanizm awansów naukowych - co szczególnie było widoczne w sferze awansów habilitacyjnych i profesorskich. 
- lata 90.: demokratyzacja uczelni wyższych - ustawa z dnia 12 września 1990 r. o szkolnictwie wyższym - m.in.: demokratyczny, niekontrolowany przez państwo wybór organów jednoosobowych wyższych uczelni, pochodząca z wyborów Centralna Komisja do Spraw Stopni Naukowych i Tytułów oraz w trybie wyborczym wyłaniani dwaj kandydaci na jej przewodniczącego, który był powoływany przez Prezesa Rady Ministrów; pochodzący z ogólnokrajowych wyborów członkowie nowo powołanego Komitetu Badań Naukowych.

2. Modyfikowane - ale nie zawsze w projakościowym kierunku - szkolnictwo wyższe „rozwijało się” przede wszystkim ilościowo (przy chronicznym jego niedofinansowaniu): powoływanie uniwersytetów z przymiotnikiem w nazwie, przyjęcie tzw. systemu bolońskiego, rozrost niepublicznego szkolnictwa wyższego i związane z tym obniżanie standardów kształcenia, obniżanie kryteriów oceny wniosków o powoływanie nowych kierunków studiów przez uczelnie (w szczególności uczelnie niepubliczne i kierunki atrakcyjne, np. psychologia) przez Polską Komisję Akredytacyjną PKA. To też miało wpływ na poziom awansów naukowych, gdyż nowe uczelnie wymagały kadry doktorów i samodzielnych pracowników nauki (temu też służył/służy kuriozalny art. 21a ustawy o stopniach naukowych i tytule naukowym...).

3. Powołanie i wspieranie - właśnie poprzez przemyślane i transparentne działania - Narodowego Centrum Nauki NCN - mądrze rozbudowanego systemu grantów indywidualnych, co też zaowocowało badaniami naukowymi, których wyniki dały podstawę do awansów doktorskich i habilitacyjnych.

4. Obniżanie (od kilkunastu lat) standardów w zakresie awansów naukowych: zbyt niskie wartości progowe, jeśli chodzi o przyznawanie jednostkom naukowym uprawnień do nadawania stopni naukowych, oraz nieprowadzenie w tym zakresie polityki projakościowej; zbyt dużo jednostek naukowych zabiega o uzyskanie takich uprawnień i to trzeba jak najszybciej zmienić. Zmian wymaga też obowiązująca (i rzez lata tylko rozbudowywana) klasyfikacja dziedzin nauki i dyscyplin naukowych - trzeba ją radykalnie „odchudzić” i powiązać np. z klasyfikacją OECD (por. przyp. 8). Duża (zbyt duża) liczba doktorów nie przekłada się na podniesienie poziomu badań naukowych i szkolnictwa wyższego w Polsce. Tu nie występuje proste powiązanie. Zbyteczne są też nowe procedury doktorskie. Poprawiajmy, korzystając z nagromadzonych doświadczeń, system, a nie rozbudowujmy go.

\section{$* * *$}

A jaka jest rola państwa w obszarze: kształcenia, prowadzenia badań naukowych i przeprowadzania awansów naukowych? Pisał Karl Jaspers (1945/2017, s. 166):

Państwo chroni i toleruje uniwersytet jako przestrzeń wydzieloną z obszaru oddziaływań swej władzy, zabezpieczając go przed skutkami innych działań władczych. [...] Państwo nadaje uniwersytetowi prawa i udziela mu środków po pierwsze z my- 
ślą o prowadzeniu badań, aby dokonywało się kontemplatywne poznawanie mające wymiar powszechny, po drugie - aby zawody wykonywane w obrębie społeczeństwa znalazły tu swą strawę duchową, swą formacyjność, swe wychowanie oraz naukową wiedzę potrzebne w praktyce. W ten sposób uniwersytet służy każdorazowo państwu i społeczeństwu. Dlatego wraz z przemianami społeczeństwa i zawodów zmienia się też jego ksztalt.

I jak mawiał Tadeusz Kotarbiński, powinno być „spolegliwym opiekunem”.

\section{Literatura}

Antonowicz, D. (2015). Między sitą globalnych procesów a lokalną tradycją. Polskie szkolnictwo wyższe $w$ dobie przemian. Toruń: Wyd. Nauk. UMK.

Antonowicz, D., Brzeziński, J. (2013). Doświadczenia parametryzacji jednostek naukowych z obszaru nauk humanistycznych i społecznych 2013 - z myślą o parametryzacji 2017, Nauka. 4: 51-85.

Antonowicz, D., Gorlewski, B. (2011). Demograficzne tsunami. Raport Instytutu Sokratesa na temat wphywu zmian demograficznych na szkolnictwo wyższe do 2020 roku. Warszawa: Instytut Rozwoju Kapitału Intelektualnego im. Sokratesa.

Brzeziński, J. (2015a). Jeżeli oceniać (jednostki naukowe i badaczy), to JAK oceniać. Przeciwko $I F$, a za peer review. Nowotwory. Journal of Oncology. 65: 476-480.

Brzeziński, J. (2015b). O konieczności utrzymania habilitacji w Polsce. Nowotwory. Journal of Oncology. 65(4): 292-297.

Brzeziński, J. (2016). Przeciwko depersonalizacji i nadmiernej standaryzacji procesu ewaluacji w nauce. Zagadnienia Naukoznawstwa. 52(1): 127-137.

Brzeziński, J., Doliński, D. (2014). O tym, co ważne w ocenie artykułów, projektów badawczych i wniosków awansowych w naukach społecznych. Nauka. 2: 33-65.

Brzeziński, J., Izdebski, H. (2016). Jak prawidłowo nadać habilitację? Forum Akademickie. 1: 24-25.

DORA (2012). San Francisco Declaration on Research Assessment. Putting science into the assessment of research. http://www.ascb.org/files/SFDeclarationFINAL.pdf.

EASE (2012). Oświadczenie Europejskiego Stowarzyszenia Redaktorów Naukowych (European Association of Science Editors - EASE) w sprawie niewłaściwego stosowania wskaźników oddziaływania (IF, impact factors). Nowotwory. Journal of Oncology. 2(62): 139-140.

Jaspers, K. (1945/2017). Idea uniwersytetu. Warszawa: Narodowe Centrum Kultury.

KSEN. Komisja do Spraw Etyki w Nauce, Polska Akademia Nauk (2016). Kodeks etyki pracownika naukowego (wyd. 2). https://instytucja.pan.pl/images/2016/komisja_etyki/ Kodeks_etyki_pracownika_naukowego_-_wydanie_II_-_2016_r.pdf.

Towpik, E. (2015). IF-mania: Journal Impact Factor nie jest właściwym wskaźnikiem oceniania wyników badań naukowych, indywidualnych uczonych ani ośrodków badawczych. Nowotwory. Journal of Oncology. 65: 465-475.

Wojtczak, K. (2016a). O stopniach naukowych w Polsce Ludowej. Część 1. Niższe stopnie naukowe. Studia Prawa Publicznego. 1(13): 27-65. 
Wojtczak, K. (2016b). W kwestii wyższego stopnia naukowego doktora w Polsce Ludowej. Studia Prawa Publicznego. 4(16): 33-57.

Wojtczak, K. (2017a). Habilitacje w Polsce Ludowej. Część 1. Warunki i przebieg habitacji w prawie szkół wyższych. Studia Prawa Publicznego. 1(17): 25-62.

Wojtczak, K. (2017b). Habilitacje w Polsce Ludowej. Część 2. Warunki i przebieg habilitacji w prawie o stopniach i tytułach naukowych. Studia Prawa Publicznego. 2 (18): 43-82.

Wróblewski, A. K. (2017). Nie wszystko, co się liczy, da się policzyć... Nauka. 1: 7-22.

Zakrzewski, J. (2012). O reformie nauki. PAUza Akademicka. 154: 2-3.

ZEN. Zespół do Spraw Etyki w Nauce (2011). Dobre praktyki w procedurach recenzenckich w nauce. Warszawa: Ministerstwo Nauki i Szkolnictwa Wyższego. http://www.e-finanse.com/pliki/Dobre_praktyki_recenzyjne.pdf.

Żylicz, M. (2008). Wypowiedź w dyskusji o polskich czasopismach naukowych. PAUza Akademicka. 14(3).

Żylicz, M. (2015). Towpik E. IF-mania: Journal Impact Factor nie jest właściwym wskaźnikiem oceniania wyników badań naukowych, indywidualnych uczonych ani ośrodków badawczych. Głos w dyskusji. Nowotwory. Journal of Oncology. 65: 465-475.

\section{Akty prawne}

Obwieszczenie Ministra Szkolnictwa Wyższego z dnia 10 października 1956 r. w sprawie ogłoszenia jednolitego tekstu ustawy z dnia 15 grudnia 1951 r. o szkolnictwie wyższym i o pracownikach nauki. Dz.U. 1956, poz. 205.

Obwieszczenie Ministra Szkolnictwa Wyższego z dnia 15 kwietnia 1965 r. w sprawie ogłoszenia jednolitego tekstu ustawy z dnia 5 listopada 1958 r. o szkolnictwie wyższym. Dz. U. 1965, poz. 114 .

Obwieszczenie Ministra Szkolnictwa Wyższego z dnia 17 stycznia 1969 r. w sprawie ogłoszenia jednolitego tekstu ustawy z dnia 5 listopada 1958 r. o szkolnictwie wyższym. Dz.U. 1969, poz. 31.

Obwieszczenie Ministra Nauki i Szkolnictwa Wyższego z dnia 11 września 1985 r. w sprawie ogłoszenia jednolitego tekstu ustawy z dnia 4 maja 1982 r. o szkolnictwie wyższym. Dz.U. 1985, poz. 201.

Rozporządzenie Ministra Nauki i Szkolnictwa Wyższego z dnia 8 sierpnia 2011 r. w sprawie obszarów wiedzy, dziedzin nauki i sztuki oraz dyscyplin naukowych i artystycznych. Dz.U. 2011, poz. 1065 .

Rozporządzenie Ministra Nauki i Szkolnictwa Wyższego z dnia 1 września 2011 r. w sprawie kryteriów oceny osiągnięć osoby ubiegającej się o nadanie stopnia doktora habilitowanego. Dz.U. 2011, poz. 1165 .

Rozporządzenie Ministra Nauki i Szkolnictwa Wyższego z dnia 26 września 2016 r. w sprawie warunków prowadzenia studiów. Dz.U. 2016, poz. 1596.

Rozporządzenie Ministra Nauki i Szkolnictwa Wyższego z dnia 30 września 2016 r. w sprawie szczegółowego trybu i warunków przeprowadzania czynności w przewodach doktorskich, w postępowaniu habilitacyjnym oraz w postępowaniu o nadanie tytułu profesora. Dz.U. 2016, poz. 1586. 
Rozporządzenie Ministra Nauki i Szkolnictwa Wyższego z dnia 12 grudnia 2016 r. w sprawie przyznawania kategorii naukowej jednostkom naukowym i uczelniom, w których zgodnie z ich statutami nie wyodrębniono podstawowych jednostek organizacyjnych. Dz.U. 2016, poz. 2154.

Ustawa z dnia 15 grudnia 1951 r. o szkolnictwie wyższym i o pracownikach nauki. Dz.U. 1952, poz. 38 .

Ustawa z dnia 5 listopada 1958 r. o szkolnictwie wyższym. Dz.U. 1958, poz. 336.

Ustawa z dnia 31 marca 1965 r. o stopniach naukowych i tytułach naukowych. Tekst jednolity wprowadzony obwieszczeniem Ministra Nauki i Szkolnictwa Wyższego z 11 września 1985 r. Dz.U. 1985, poz. 202.

Ustawa z dnia 12 kwietnia 1973 r. o zmianie przepisów dotyczących stopni naukowych i tytułów naukowych oraz organizacji instytutów naukowo-badawczych. Dz.U. 1973, poz. 89.

Ustawa z dnia 4 maja 1982 o szkolnictwie wyższym. Dz.U. 1983, poz. 113.

Ustawa z dnia 12 września 1990 r. o szkolnictwie wyższym. Dz.U. 1990, poz. 385.

Ustawa z dnia 12 września 1990 r. o tytule naukowym i stopniach naukowych. Dz.U. 1990, poz. 386.

Ustawa z dnia 14 marca 2003 r. o stopniach naukowych i tytule naukowym oraz o stopniach i tytule w zakresie sztuki. Dz.U. 2003, poz. 595, t.j. Dz.U. 2016, poz. 882, 1311; 2017, poz. 859 .

Ustawa z dnia 27 lipca 2005 r. Prawo o szkolnictwie wyższym. t.j. Dz.U. 2016, poz. 1842, 1933, 2169, 2260; 2017, poz. 60, 777, 859 .

Ustawa z dnia 30 kwietnia 2010 r. o zasadach finansowania nauki. Dz.U. 2010, poz. 615; t.j. Dz.U. 2016, poz. 2045, 1933, 2260; 2017, poz. 859.

Ustawa z dnia 21 kwietnia 2017 r. o zmianie ustawy o stopniach naukowych i tytule naukowym oraz o stopniach i tytule w zakresie sztuki oraz niektórych innych ustaw. Dz.U. 2017, poz. 859 .

\title{
On correcting (and spoiling) the system of academic promotions in Poland in 1990-2017
}

\begin{abstract}
The paper presents the key problems of the Polish system of academic promotions conducted in higher education institutions and institutes of the Polish Academy of Sciences. The issue discussed is conferring - by legitimate scientific units - scientific degrees of $\mathrm{PhD}$ and habilitation (postdoctoral degree). The author, following the presentation of these issues in Poland under communism (1945-1989), focuses on showing the evolution of the system of academic promotions, both a positive and a negative, spoiling the system, one. The paper refers (in its evidence dimension) to fundamental legal acts (laws and regulations) which regulate the functioning of higher education institutions and - in particular - the procedures of academic promotions. In the last decade or so, phenomena have been emerging which raise serious concerns in this field. The phenomena in question require actions which would make the system more efficient (without depriving universities of their autonomy). What is needed is a constructive dialogue between the state and the university.
\end{abstract}

KEYWORDS: university, scientific degrees, $\mathrm{PhD}$ and habilitation, autonomy, Ministry of Science and Higher Education, scientific research and scientific promotions 
CYTOWANIE: Brzeziński, J.M. (2017), O poprawianiu (ale też i o psuciu) systemu przeprowadzania awansów naukowych w Polsce w latach 1990-2017. Nauka i Szkolnictwo Wyższe. 2(50): 147-172. DOI: 10.14746/nisw.2017.2.7.

JERZY MARIAN BRZEZIŃSKI - ur. w 1947 r. w Pelplinie; prof. zwycz. w Instytucie Psychologii UAM w Poznaniu (dyrektor w latach 1999-2016); członek rzeczywisty PAN, przewodniczący Rady Kuratorów Wydziału Nauk Humanistycznych i Społecznych PAN (od 2011 r.), członek Prezydium PAN (od 2007 r.). Jest członkiem: Centralnej Komisji do Spraw Stopni i Tytułów (od 1991 r.), Komitetu Psychologii PAN i Komitetu Etyki w Nauce PAN, a także ekspertem Polskiej Komisji Akredytacyjnej. Jest redaktorem naczelnym czasopism: Nauka i Poznańskie Studia z Filozofii Nauki (wspólnie z: Krzysztofem Łastowskim) oraz serii wydawniczych: „Wykłady z psychologii”, „Nowe tendencje w psychologii”. Zainteresowania naukowe: filozofia nauki, metodologia psychologii, diagnostyka psychologiczna, psychometria, naukometria, etyka zawodu psychologa, idea uniwersytetu. Jest autorem licznych prac z zakresu metodologii (w tym: Metodologia badań psychologicznych oraz Badania eksperymentalne $w$ psychologii i pedagogice), psychometrii, diagnostyki psychologicznej, zastosowań metod statystycznych w badaniach społecznych, etyki zawodu psychologii (w tym: Etyka zawodu psychologa; współautorzy: B. Chyrowicz, M. Toeplitz-Winiewska, Z. Toeplitz) oraz naukoznawstwa. Doktor honoris causa Uniwersytetu Kazimierza Wielkiego w Bydgoszczy i Uniwersytetu Gdańskiego; profesor honorowy Uniwersytetu Śląskiego; odznaczony Krzyżem Oficerskim Orderu Odrodzenia Polski. E-mail: brzezuam@amu.edu.pl. 